\title{
The Palestinian Pessoptimist and the American Holy Land: Simpson's Stylistic Model of Satirical Humour in Application
}

\author{
Muhammad J. H. Abdullatief ${ }^{1}$ \\ ${ }^{1}$ English Department, Faculty of Al-Alsun (Langauges), Minia University, Minia, Egypt \\ Correspondence: Muhammad J. H. Abdullatief, English Department, Faculty of Al-Alsun (Langauges), Minia \\ University, Minia, Egypt. E-mail: mjha2@le.ac.uk
}

Received: November 28, 2013 Accepted: December 28, 2013 Online Published: February 20, 2014

doi:10.5539/ells.v4n1p22 URL: http://dx.doi.org/10.5539/ells.v4n1p22

\begin{abstract}
This paper enquires into the use of satire, especially literary satire. Focusing on two culturally different satirical novels (The Pessoptimist and The Holy Land), it attempts to identify the techniques of producing satire and the conditions needed for comprehending it. It aims at testing the applicability of Simpson's Model of Satirical Humour to literary satirical works and especially those written in Arabic. An analysis of a Palestinian satirical novel in comparison with an American one is provided. Such analysis focuses on the linguistic characteristics of Arabic that may highlight it as more satirical and gives prominence to science fiction as a vehicle for satire. The effective role of stylistic techniques and pragmatic principles is introduced in analysing literary works in general and satirical works in particular. Through discussing the components of the stylistic model, the reader's role in achieving the satirical effect of satirical works is foregrounded and more elaboration is given to the metaphoric satirical techniques. Finally, the paper proposes a couple of modifications to the model in relation to both the satirical techniques and the satirical uptake process.
\end{abstract}

Keywords: satirical humour, Simpson's model, stylistic analysis, The Pessoptimist, The Holy Land

\section{Introduction}

In the seventeenth and eighteenth centuries, satire was believed to be a prominent form of literary composition, i.e., a literary genre with specific characteristics. However, at present, linguists and literary scholars find that the term satire is "a curious and rather elusive one" (Simpson, 2003, p. 4), and so it is "a somewhat slippery term to define" (Opitz, 2007, p. 74). Since the first attempt to define satire, scholars have not reached a single definition for it. This is because of two reasons. Firstly, each scholar seems to define satire from the aspect that concerns him/her the most. For example, interested in the purpose of satire, Randall $(1974$, p. 13) defines it as "criticism made with the hope ... that there will be reform" and Berger (1997, p. 167) describes it as "the deliberate use of the comic for purposes of attack". Emphasizing the boundaries of satire and its relation to humour, Ashworth (1967, p. 101) defines it as "a joke about serious things within a moral framework. It criticizes and provokes humour at the same time". Focusing on what it does to its subjects, satire is defined as the ridicule of a subject to reveal its shortcomings and undervalue it (Beckson \& Ganz, 1989; Kreuz \& Roberts, 1993) and "a primary technique for deflating egos and providing social criticism" (Gring-Pemble \& Watson, 2003). Focusing on its relation to historic individuals and passed events (and therefore cultural and social background), Rosenheim (1971, p. 323) defines satire as "an attack by means of a manifest fiction upon discernible historic particulars".

Secondly, the difficulty of defining satire seems to stem from its ability to mimic other forms. Over ages satire has undergone some sort of "transhistorical (re)formation" (Simpson, 2003, p. 65). Early examples of satire can be found in the ancient Egyptian literature. The Satire of the Trades, for instance, is an Egyptian writing from the beginning of the 2 nd millennium $\mathrm{BC}$ in the form of an instruction. It uses an exaggeratedly negative tone to describe professions other than the scribal profession (see Lichtheim, 2006, pp. 184-193). Examples of satire in ancient Greece are the plays of Aristophanes (450-388 BC), the Greek dramatist whose plays are known for their critical political and societal commentary ("Aristophanes", 2013). Another form of satire in ancient Greece is named after Menippus (3rd century BC), a Greek Cynic and satirist. The Menippean satire, usually in prose, is characterized by attacking "mental attitudes" more than specific individuals (Frye, 1957, p. 309). In ancient Rome, satire appeared in the form of poetry in the works of the two most prominent and influential ancient Roman satirists, Horace (65-8 BC) and Juvenal (the late 1st and early 2nd century AD). Satire emerged in the Medieval Arabic 
world in the form of poetry as well, most notably in the works of the two well-known poets Jarier and Al-Farazdaq (Note 1). In the 9th century, satire was introduced into Arabic prose by Al-Jahiz to discuss serious topics relating to anthropology, sociology and psychology in a satirical approach (Bosworth, 1976, p. 32). In Medieval Europe, satirical poetry is believed to have been popular. It was plentiful in 14th c., for example, in Chaucer's Contemporary Tales (Cuddon, 1999, p. 782). In the 18th century, Jonathan Swift, one of the greatest Anglo-Irish satirists, was of the first to practise satire in a modern journalistic form. His A Modest Proposal (1729) satirizes indifference to the plight of the desperately poor Irish people. Satirizing the flaws in human society in general and English society in particular, Swift's Gulliver's Travels (1726) presented satire in the form of a novel. In the Victorian era, practicing satire in a journalistic form developed with the foundations of several satiric papers such as Punch (1841) and Fun (1861). In the same period, a satirical novel by a great American satirist, Mark Twain's Huckleberry Finn (1885), was published in the United States. In the 20th century, satire was used by famous novelists such as Sinclair Lewis, Aldous Huxley and George Orwell. In the 1950s, satire began to take the form of stand-up comedy in the United States, most prominently by Lenny Bruce and Mort Sahl. Currently, satire is used in various forms whether they are literary works (poetry or prose), newspaper or magazine articles, theatrical works, visual arts (painting, sculpture, film, TV, etc.), musical texts or songs, or oral storytelling presentations. Therefore, satire can not be restricted to any literary form, nor to any type of media, nor to any culture at whatever stage (Test, 1991, p. 8).

Not meant to be a historical documentation of the development of satire, the above lines indicate that satire is not a genre in itself nor has a distinctive form but it needs to adopt other forms to express its ideas (Ball, 1995; Feinberg, 1972; Harris, 2004; Knight, 2004; Opitz, 2007). That is why this paper deals with satire as "a spirit expressed through other forms" (Test, 1991, p. 10), "a mode of discourse or vision" (Preminger \& Brogan, 1993, p. 1114), "a mode of humorous communication" (Simpson, 2003, p. 43), "a mental position" (Knight, 2004, p. 4), or "a culturally situated discursive practice" (Simpson, 2003, p. viii).

\section{Study of Satire}

The various forms of contemporary satire mentioned above imply how satire is as much a common part of everyday spoken and written interaction as any of the other humour practices such as jokes, witticisms, puns, humorous anecdotes, etc. It is odd to find that satire is so rarely analyzed by linguistic scholars interested in humour. It seems that, with the exception of Simpson (2003), no devolved, comprehensive theoretical framework for the study of satirical discourse can be found in linguistic studies of humour. There are merely a few article-length studies focussing on certain aspects of the production and reception of satirical humour. For example, using a cognitive approach, Pfaff and Gibbs (1997) attempt to figure out to what extent readers are aware of authorial intentions when they read stories that appear to be satirical. Such partial studies, concentrating on specific aspects, are not able to account for the relatively complex nature of satire. The paucity of research in this field of study may be because of the assumption that analyzing satire has become the exclusive preserve of literary criticism.

There are indeed many studies by literary critics which explicitly focus on satire. Some literary studies discuss satire in the light of broad critical theories of literary phenomena. Gill (1995), for instance, draws on ideas in postmodernism for the principal theoretical perspective of all essays in his book. Viewing satire as a distinct form of textual organisation, other literary studies tend to focus on certain satirical forms or on the satirical styles of specific writers. For example, the study of Weinbrot (1988), which focuses mainly on the satire of Alexander Pope, views satire in the form of satirical verse. In general, in literary criticism, the conceptualisation of satire as a form of discourse is not clear. Although they raise significant implications for the understanding of what satire is, its purposes and its relation to humour, literary critical studies lack any systematic account of the linguistic properties of satire. They tend to use affective judgments and discuss the status of satire as a literary canonical genre. Moreover, such studies provide no theorization in relation to satire's reception in a humour community (see further Simpson, 2003, pp. 47-67).

Because it provides linguistic criteria for the definition of satire as discourse and postulates a set of contextual constraints that operate on the production and reception of satire, Simpson's (2003) model of satirical humour is used in this paper for analyzing the satirical texts under study. Simpson's model is based on the idea that satire functions at a higher level of discourse than genre or register. Satire is configured as a triad embodying three discursive subject positions: the satirist, the satiree and the satirized. Satire is characterised by multiple forms of irony: three principal ironic phases exist in the creation of a satirical text. The construction of satirical text involves the combination of and opposition between two elements: a prime and a dialectic, which function as interdependent structural slots in discourse. Those elements manifest themselves through the satirical method containing techniques that can be classified into two categories: metonymic satirical method and metaphoric 
satirical method. While the prime element is a stage which is characterised by irony in its echoic mode, the dialectic element is a stage which is characterised by irony in its oppositional mode. Satirical uptake requires a special configuration of Habermas's (1979) universal validity claims: sincerity, appropriateness and truth. The collision between those universal validity claims triggers an "irony of conferral", the third ironic phase.

In this paper I attempt to test Simpson's model in different cultural contexts. The model is applied to two satirical novels written in two different languages and expressing two different cultures: Robert Zubrin's The Holy Land and Emile Habiby's Al-Waqaea Al-Ghareeba fi Ikhtifaa Saeed Abi Al-Nahs Al-Mutashael "The Secret Life of Saeed the Ill-fated Pessoptimist" (The Pessoptimist). The novels provide two different methods of dealing with the same subject matter, the unfolding Israeli-Palestinian conflict. The Holy Land is a science fiction satire written in English by an American author. It satirizes the conflict in the Middle East between Israel and the Palestinians. It is a story about a group of very advanced, peaceful aliens (Minervans) who have taken over a small town in the US which they claim as their ancient homeland. The Christian fundamentalist leader of the US more concerned with power than right uses every dirty trick in the book to try to get them out and return "the holy land" (kennewick) to its own (human) inhabitants. After the evacuation of the aliens, the story ends with news about a great revolution that causes the murdering of all of the country's duly elected government leaders - pure chaos. On the other hand, The Pessoptimist is an Arabic satire written by a noted Palestinian writer and politician about the Israeli-Palestinian conflict and one of the first examples of Israeli Arab literature. It tells the secrets of a Palestinian who becomes a citizen of Israel, describing the crucial problem of Palestine, the tortuous experience, the hardships, and the underprivileged status of the Palestinian Arab population which remained in the State of Israel after the mass evacuations following the two wars of 1948 and 1967.

\section{Prime Phase}

The prime is the first ironic phase of satire, the echoic irony. Wilson and Sperber, in their echoic theory (first published in Sperber and Wilson 1981 and developed in a series of later works, e.g., Sperber \& Wilson, 1995, 1998; Wilson \& Sperber, 1992, 2012), propose that irony functions as an echoic interpretation of a previous utterance, belief, or expectation. In other words, the satirist echoes a thought (e.g., a belief, an intention, a norm-based expectation) or an utterance with a similar content to a previous thought attributed to an individual, a group, or to people in general, in order to express a critical or mocking attitude to it (Wilson, 2006, 2012). Simpson (2003) argues that satirical discourse requires an echoic mention as the first phase for satire - that is, satire requires some prior discourse, utterance, or speaker to comment upon.

Related to the echoic characteristic of irony is what Kreuz and Glucksberg (1989, p. 375) call echoic reminder theory. They argue that this term highlights the reminder function of echoic utterances and that "although all ironic utterances accomplish their communicative intent by reminding listeners of some antecedent event, not all such reminders are 'echoic' - that is, not all antecedent events are actual or even implied utterances". Satire does more than reminding audiences of previous utterances, norms, or expectations; it re-contextualizes them, placing them in a new discursive context.

In literary satirical works, as in the two novels under study, there is more than a prime domain as a satirical novel appears to consist of small connected satirical pieces. The prime domain differs from one satirical piece to another. Prime domains may be political, religious, scientific, technical, relating to business, etc.; it depends on the satirized or the target of the satirical discourse. Because the prime and dialectic elements are mutually interdependent, Simpson (2003, p. 103) argues, "the perception of a dialectic element is often the key to identifying the presence of a prime". Therefore, to discover what prime elements are used by Zubrin and Habiby in their satires, their satirical methods need to be clarified.

\section{Dialectic Phase}

Unlike the prime phase which is based on the echoic characteristic of satire and draws upon the satirees' world knowledge, the dialectic phase depends on text-internal discourse strategies and on the satirees' knowledge of typical discourses. The satirical method, involved in the model, is composed of the linguistic devices used by the writer to create the prime and dialectic elements of the satirical discourse. The Satirical methods of the novels are analysed in accordance with the model's two-way categorization: metonymic satirical method and metaphoric satirical method.

\subsection{Metonymic Satirical Method}

Certain discourse techniques used in composing a dialectic element in satire can be classified as metonymic, because the operations they perform fall within the same conceptual domain, i.e., the prime and the dialectic elements belong to one domain. These satirical techniques include saturation, attenuated focalization, and 
negation.

\subsubsection{Saturation}

The term saturation is used to refer to the technique of exaggeration, which functions as an inflating strategy within a particular order of discourse. Zubrin uses it to criticize political affairs, the foolishness of some western regulations and laws, and the Earthling administration and their economic policy in addition to social issues. Feminism, for instance, is satirized in a long conversation between the most prominent two characters in the novel, Aurora and Hamilton (pp. 65-66), in which Zubrin's use of saturation is easy to observe. It is full of elements of paradox and oxymoron especially in the words of Aurora, e.g., "We have hardly any power at all. All we control is religion, government, science, education, and life inside the home"; "But the cause of women's rights is advancing, and I think that someday we will obtain equality"; and "All we get to do is to decide on war or peace, and then tell them who to attack, when to attack, when to treat, and what weapons and tactics they can use. All the rest is entirely under their control". Oxymoron can be found in examples like "only 90 percent", and "only 99 percent". Although women now have rights more than those of men, they still fight for more rights.

In The Pessoptimist, saturation is widely used by Habiby to make prominent some features of Saeed's character such as his pessoptimism, self-interest, indifference, cowardice and exaggerated way of dealing with people. In addition to criticizing the Israeli government's excesses in arresting Arabs, Habiby, using this device, satirizes the exaggeration of the Arabic newspapers that write about incidents of Arabic victory contrary to fact until people become unable to differentiate between victory and defeat:

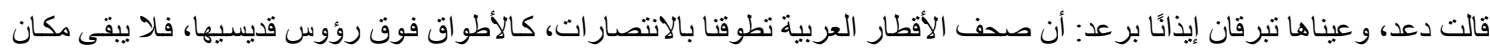

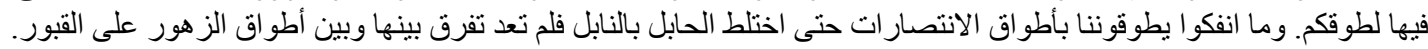

Yuaad, her eyes glittering in anger, commented, "The papers of the Arab world cordon us with news of 'victories,' like haloes over the heads of saints; there's no space for reports of your cordons. They've kept on encircling us with cordons of their victories, until there's nothing but chaos and we can no longer differentiate between them and the wreaths of flowers set on graves." (Habiby, 2003, p. 142; Note 2)

\subsubsection{Attenuated Focalization}

Whereas saturation is essentially "more of the same", its opposite, attenuation, is "less of the same" (Simpson, 2003, p. 198). While The Pessoptimist has no example of such a technique, Zubrin uses this device craftily to satirize not only the Minervans' view of the American way of life but also the modern way of life more generally. As a way to achieve this satirical strategy, Zubrin uses the technique of defamiliarization, which itself is achieved through the use of undercoding. Instead of using the usual term for a thing, Zubrin uses a general term or description which devalues it or indicates its negative influence. This technique shows obviously how Zubrin uses science fiction as a vehicle for satire. The makeup used by the Earthling women is referred to as "mildly toxic colored substances" (p. 187) which make the Earthling women "more ugly" (p. 188). A mirror is referred to as an "optical reflecting surface" (p. 216) or a "reflector-wall" (p. 238), a hotel as "a house that provided rooms and beds to sleepers in exchange for the green tree-flesh the Earthlings used as a form of currency" (p. 96), photographs as "some slimy pieces of paper with images on them" (p. 289), petrol as "a smelly hydrocarbon fluid" (p. 291). This technique is used in various situations to indicate how primitive the Earthling weapons are: six-shooter pistols are described as "hand-wielded chemical projectiles weapons" (p. 19).

\subsubsection{Negation}

While negation, the device of inverting positive polarity in discourse, does not appear in The Holy Land, it is used in the satirical discourse of Habiby's novel to achieve different satirical purposes such as satirizing how the soldiers on the Lebanese borders treat the Palestinians crossing the borders. Saeed states:

$$
\text { فلما التقانا عائدين حيانا وسأل: أين السلاح أيها المجاهدون؟ أجاب كبيرنا: سلاحنا العلم، وما معنا شروى نقير. فلم يشأ الضابط أن يقتسهها. }
$$

When the officer met us on our return trip he asked, "Where are your weapons, my gallant warriors?" the oldest of us replied, "Our weapon is knowledge, and we have nothing." So the officer did not want to share it. (p. 34)

This antithesis in pretending that "nothing" is an entity to be shared satirizes what usually happens if crossing Palestinians have "something".

Habiby's nonuse of attenuated focalization indicates that his satirical targets need mostly to be "inflated" to appear clearly amongst the factual illogical events that happen in the Middle East every day. On the other hand, Zubrin's 
nonuse of negation is due to that his satire itself is mainly science fiction, a story with non-factual elements.

\subsection{Metaphoric Satirical Method}

Unlike the metonymic satirical method, the metaphoric method includes techniques that establish satirical relations between different conceptual domains, i.e., the prime and dialectic elements belong to two or more different conceptual domains. These techniques include combination, merging, and interdiscursivity.

\subsubsection{Combination}

When elements of two or more different conceptual domains are combined together to compose a final satirical image, this technique is called combination. Through combination, Zubrin criticizes the separation between the Western Galactic world and those worlds they consider primitive. This idea reflects the separation of the developed countries, in the real world, from the Third World countries. Zubrin likens the Western Galactic surroundings in addition to the Minervan ones to paradise and the "primitive" world to hell. In producing the two final satirical images, Zubrin combines different domains such as women, drinks, means of transportation, living places, and streets. Combination is also used when conferring the quality of concreteness upon abstract things or combining animal behaviors with human bodies to satirize the American mobs' behavior that makes them seem like animals rather than human beings. In the incident of the Yankee Stadium, "hundreds of floats depicting the Milky Way Galaxy were paraded into the playing field of the stadium ... Surrounding each effigy galaxy, the rioters pulled down their pants and started urinating on its western spiral arm" (p. 38). Moreover, one of Kolta Bruna's reports shows "images of people defecating on effigies of the Western Galactic Arm, and then dancing on their manure, trampling it into the face of portraits of the Empress Minaphera, which were laid on the ground for this purpose" (p. $81)$.

In the same way, Habiby uses this metaphorical strategy for different satirical purposes. He finds it a good tool to satirize Saeed's cowardice and way of thinking, the military polices of Israel, their way of treating the Palestinian people, and Israel's conception of weapons. In this novel, combination comes to be shown in terms of semantic equivalence of two different ideas or, pragmatically speaking, propositions. Two entities are shown to be equivalent usually to devalue one of them. This semantic equivalence mainly appears through grammatical parallelism. During his first meeting with the military governor, Saeed states:

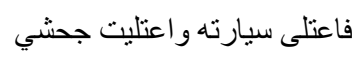

He climbed into his jeep and I mounted my donkey. (p. 14)

Although the two clauses have two different verbs, both verbs are merely two translations of one Arabic verb " عil" to climb or mount. Thus "his jeep" and "my donkey" are objects of the same verb in two different clauses of the same grammatical form: SVO. The semantic difference between the two objects satirizes the social difference between the subjects.

\subsubsection{Merging}

Another metaphoric technique is merging in which elements of two different conceptual domains are merged together resulting in one satirical effect. This strategy is used by Zubrin to achieve some satirical purposes. Thoughts, for example, are likened to liquid - a tangible thing. People are likened to animals especially dogs; Zubrin indicates how people of the Western Galactic Empire inwardly think of the Americans. This happens during Junea's talk with her Princess: referring to the American President, Junea says, "throw him that bone, and he's yours" (p. 233). This use of dehumanization, when human beings are likened to animals or things, indicates how the human and animal domains are merged.

Habiby uses merging to criticize how his country was, and still is, a victim of different colonizers. Personification is a particular kind of merging in which the domain of the thing personified is merged into the domain of humans. The opposite method, dehumanization, is also used to criticize the bad way in which the Arab citizen is being treated in Israel. More than one time, Habiby refers to hunger as "أبو عمرة"Abu Umra" — an agnomen. This agnomen has been used in a way as if referring to somebody not something:

$$
\text { فطلقها حين وجدها تخونه مع الرغيف بن أبي عمرة، من غور الجفتلاك، الذي طلقها في بير السبع. }
$$

He divorced her when he found she had deceived him with Loaf, son of Hunger, from the Jaftlick lowlands, who in turn divorced her in Beersheba. (p. 8)

Habiby satirizes how Saeed's ancestors were poor to the extent that one divorced his wife to find her eat a loaf 
alone. Thurayya, an Arab woman, was poor too:

$$
\text { عاثت [نريا] في عمان مع زوجها وطفلها وأبي عمرة الذي رحمها فلم تتجب منه أطفالا. }
$$

She [Thurayya] lived in Amman with her husband and children and with hunger that was merciful for not having children by her. (p. 93)

\subsubsection{Interdiscursivity}

When two different discourses of two different conceptual domains are related together, this technique is named interdiscursivity. This relation is established when one discourse imports some elements from another discourse. Interdiscursivity refers to "the mixing of diverse genres, discourses, or styles associated with institutional and social meanings in a single text" (Jianguo, 2011, p. 96). The term is widely discussed by Fairclough (1992) when he accounts for the more overarching concept of "intertextuality".

Zubrin uses this technique to criticize the American government's bad treatment of the American citizens, how the Western people including the Minervans are overwhelmed by technological affairs in a way that covers feelings and passions, and the misconceptions of the American citizens. With the intent of revenge, one of the men who want to commit a destructive action against a Western flagship says, "In the name of Jesus, I command thee, pagan pilots, accelerate thy vessel and smite the flagship of the Whore of Babylon!" (105). Contrary to expectation, the phrase "in the name of Jesus" is used to initialize a destructive order of killing innocent people - an order which is the opposite of what Christianity calls for. Furthermore, the use of old English words such as thee and thy evokes features of the biblical discourse in which such an action is totally refused. This implies how crime discourse imports elements of religious discourse in the novel.

In his novel, Habiby seems to be affected by the discourse of the Holy Quran using expressions based on Quranic ones. For example, the Quranic verse:

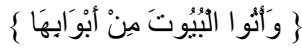

$$
\begin{aligned}
& \text { (البقرة, v. 189) }
\end{aligned}
$$

"Enter houses through their proper doors" (ch. Al-Baqara, v. 189; Note 3). It can be recalled when reading what Habiby writes about the Israeli authorities:

$$
\text { وكانو ا يدخلون البيوت، من أبو ابها، في كل لحظة، بحنّا عن هؤلاء المتسللين. }
$$

They were entering houses, through their proper doors, any moment, searching out infiltrators. (p. 57)

Although they enter houses through the proper doors, the authorities do this any moment of the day or night without permission of their owners. The right way of entering houses is replaced by a wrong way through importing elements of a religious discourse.

While the metaphoric strategy of combination plays equal roles in both The Holy Land and The Pessoptimist, Zubrin, unlike Habiby, depends on merging more than interdiscursivity. Habiby's vast knowledge of various Arabic discourses, which is prominent in the novel, explains his heavy use of interdiscursivity.

\subsection{Satirical Hooks}

Satirical hooks are those lexico-grammatical devices that often establish, embellish and sustain connections between the features of discourse that expound the prime, on the one hand, and the dialectic on the other (Simpson, 2003, pp. 9-10). In literary satirical works, they adorn and support the basic framework of satire as a whole. In the two novels, the satirical hooks manifest themselves in terms of satirical names of characters and different types of puns.

\subsubsection{Names of Characters}

Both writers have used the names of their characters in a certain way that makes them satirical to some extent. Names of characters play a more prominent role in The Pessoptimist than in The Holy Land. The main part of the full title of The Pessoptimist is the name of the protagonist. It is Saeed the Ill-fated Pessoptimist. The name of the protagonist Saeed, which means "happy", contradicts the name of his father the Ill-fated and this contradiction expressed by their family name, the Pessoptimist, which indicates pessimism and optimism at the same time. The title implies that readers are going to read "a heart-rending tale of defeat and rebellion, death and regeneration, terror and heroism, aggression and resistance, individual treason and communal loyalty" (Jayyusi, 2003, p. xiii). Although Saeed wants to name his son Fathy "my victory," the Israeli government compels him to name his son 
Walaa "loyalty." What is satirical is that Walaa's loyalty does not turn out to be to the Israeli government, who named him for this purpose, but to Palestine.

In his novel, Habiby mentions the name of an old lady who represents a large number of the evicted Palestinians. Her name is Thurayya Abdel-Qadir Maqboul which can be translated literally as "Pleiades the Worshipper of the Powerful Acceptable." The use of this name, taking into consideration the hardships that old lady has faced since the establishment of Israel, seems to be very satirical. The old dignified (Pleiades) has come to eat dust; her father's name indicates that she and her people are very weak. The family name indicates that they accept to live in bad conditions. Indeed, this is what happens when, after living in poverty with her husband and children, the Israeli soldiers take her wedding jewels giving her nothing in return. Referring to the Palestinian men in a general way, Habiby proposes Saeed and Saad to be examples of their names. Saad and Saeed are Arabic names that can be translated as "Happiness" and "Happy" respectively. The satirical use of these names indicates the hardships and bad conditions in which the Palestinians live.

Zubrin's use of names is not as distinguished as Habiby's; however, some characters' names seem to be satirical, especially those of the American cabinet members. Jack "The Ripper", the name of the most famous, unidentified, serial killer of all time (Keppel, Weis, Brown, \& Welch, 2005), is given to the American Secretary of Defence, whose more victims are his own people than his enemies. In spite of all her "black" deeds from fabricating evidences to inverting truth, the Public Relations Director is named Lisa White. Another member of the cabinet is named John Meade, whose last name is pronounced in the same way as the word mead which refers to an alcoholic drink. What is satirical about the name is that it is given to the White House Chaplain Reverend, the one who is supposed to have nothing to do with alcohol.

\subsubsection{Puns}

Simpson defines a pun as "a form of word play in which some feature of linguistic structure simultaneously combines two unrelated meanings" (2003, p. 20). Although puns are important elements of satirical writing in general, Zubrin does not resort to them except for one direct pun in smithereens and Smith, the name of one of the American cabinet members (p. 3).

On the other hand, puns play a major role in The Pessoptimist. They are many and varied in terms of their formal properties:

- Lexical puns are found in words such as "قرون" centuries or horns (p. 19), "عجوز النحس" ill-fated hag or Mrs

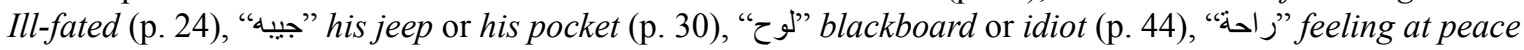
and one's palm (p. 46), "العقل" being chained or having minds (p. 51), and "ذهب" gold or went (the past of go) (p. 95).

- Phonological puns can be found between words such as "محصية" /mohsiyya/ (as Arab speakers pronounce it) being counted in the census and /moxsiyya/ (as Isreali soldiers pronounce it) eunuch (p. 53), "الحيّات /əlhəyyæt/ serpents and "الحياة" /alhəyæt/ life, pronounced in Palestinian Arabic (p. 125), or the Hebrew word Medinah /məd1:næh/ state and the Arabic word "مدينة" /mədi:nəh/ city (pp. 49-50).

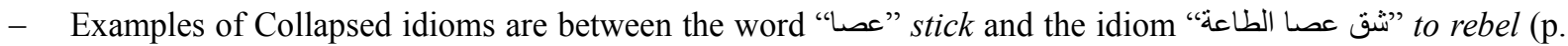

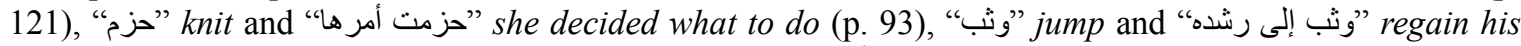
consciousness (p. 104), and "وضع" the past of put and "وضعت الحرب أوزارها" thar finished (p. 63).

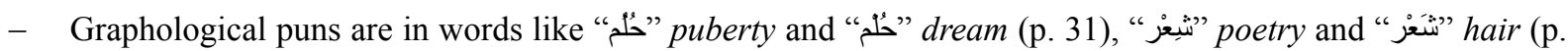

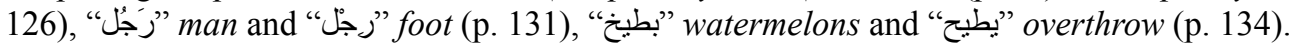

The above examples of various types of puns indicate how Habiby's style is satirically humorous and heavily culture-bound. Such a style constitutes a true challenge when translated into another language, for example, English.

\section{Satirical Uptake}

Satirical Uptake refers to the process of understanding the satirical content of a piece of writing by its reader. In addition to the policies of the U.S., Israel, and Palestine, religious extremism, and terrorism, Zubrin satirizes other targets like the manipulative media, selfish greedy politicians, religious zealots, and the faceless mob. To have the United States stand in for the Arab people was an intelligent choice by Zubrin and a number of reviews reveal how readers have reacted to The Holy Land as a satirical novel; quotations of two examples of reviews of the novel are considered:

"The Holy Land is a must-read for anyone with a social and political conscience" (Lutz, 2004).

"Science fiction satire in the tradition of Kurt Vonnegut, Jr., John Sladek, and James Morrow, effectively using wit 
and humor to frame important social issues" (Hughes, 2009).

More than 20 similar reviews can be found on Amazon website.

In the same way, The Pessoptimist has three main targets: Israel's cruel policy as a settler state; the reactionary Arab policies, represented by the Arab upper classes in Palestine; and Saeed, the protagonist of the novel, who represents a large proportion of his people. The fact that this novel has been translated from Arabic into English widens the scope of its readers. Quotations of two reviews are considered:

"On an artistic level, it is highly original and fresh. It constitutes a challenge to the existing modes of fiction in the Arab world and this because it has been written in a straight mode of satirical fiction" (محجوب, 2010, my translation).

"In The Pessoptimist, Habiby has achieved a satirical text from A to $\mathrm{Z}$ including the narrator, the characters, and the past and present" (در اج, 2004, my translation).

More than 40 similar reviews, by Arab and non-Arab readers, can be found on Goodreads website.

The above-mentioned quotations from some reviews of The Holy Land and The Pessoptimist illustrate the extent to which readers have perceived the novels as satires and therefore the collision between the prime and dialectic elements is mostly recognized. It is the presence of prime and dialectic elements and the collision between them which rescinds the text's claim to sincerity. Thus, the novel raises a claim of insincerity, i.e., the reader is invited NOT to trust the writer. This claim of insincerity needs to be supplemented by the redemption of the claim of appropriateness and the suspension of the claim of truth. Actually the claim of appropriateness has been redeemed by the confirmation by the readers that the targets of satire in the novel deserve to be satirized. Moreover, the two novels, as literary works in addition to being declared as science fiction in the case of The Holy Land, comprise a suspension of the claim to truth. This fact indicates that both Zubrin and Habiby have mostly succeeded in producing the satirical effects of their works according to Simpson's model. However, this does not mean that their satires are understood by all readers, and it is doubtful whether any satire ever is.

\section{Modifications of the Model}

Having applied Simpson's model to Zubrin's and Habiby's satires, I suggest a couple of modifications which will enhance the applicability of the model to satirical works in general and literary satirical works in particular.

\subsection{Inversion}

The first modification is represented in the addition of a new strategy suggested when I came across examples of satire that could not be analyzed using Simpson's metonymic strategies. In Simpson's balloon-and-bell-jar analogy, there are three methods of dealing with the target of satire. The first method is to inflate it. Secondly, if the balloon within the bell jar is already partly inflated, a better method is to deflate it. A third method would be to "negate" it by trying to pretend in effect that the balloon is not there at all. Actually, there is a fourth method, which Simpson has not mentioned: to invert the balloon, that is, inverting the target to be the opposite of what it should be. Whereas negation "tends to foreground nonexistent states" (Simpson, 2003, p. 137), inversion indicates an existent opposite state of affairs without using negative structures.

Zubrin, at the beginning of his novel, gives his readers a general impression of a character or a group of characters and the events of the novel prove the contrary. In chapter one, readers are told about the American President that he is "a very religious man" (2), and the President shows the very opposite during the course of the story. Moreover, at the very beginning of the story the President shows feeling of disgust towards the Minervans: "A mixture of Finns, Hungarians, and Basques. How disgusting" (1). However, throughout the rest to the story, the Minervans display these feelings towards the President. Satirizing the government's policy of treating citizens, Zubrin provides some examples. Hamilton, who is to sacrifice his life for the sake of his people, is considered a traitor and is about to be killed more than one time at the hands of his own people. Dr. Berger, the only doctor who cares about healing the maimed children, is sentenced to death as a guilty man. Lisa White, who has gone to represent the government of her country before the Western Galactic Empire, is killed as a traitor.

In The Pessoptimist, this strategy manifests itself when the writer intentionally inverts his satirical target presenting it as opposite of what it should be. The writer or one of the characters may state something and the events of the novel prove the opposite or they may state something opposite to the state of affairs in the real world. Satirizing the so-called democratic policy of Israel, Habiby presents this example. After the war, one of the mines, the soldiers left behind, exploded under some boys when returning home from school. When the Communists issued a statement including an accusation that the government had neglected to clear the road of the Israeli mines, Jacob summoned the members of the Union of Palestine Workers and said: 


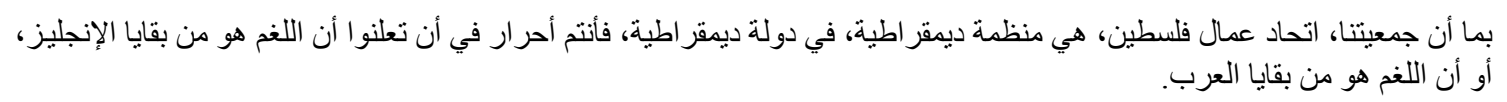

Because our association is a democratic organization in a democratic state, you are free to announce that the mine had been left either by the British or by the Arabs. (pp. 57-58)

Jacobs's words can simply be paraphrased in the following contradictory sentence: Because we are a democratic government, you are free to announce only what we want, nothing else. This indicates how the Israeli government is in fact dictatorial.

\subsection{Comprehensibility}

The second modification is related to the universal validity claims. As mentioned before, satirical "uptake" depends to a great extent on the interplay between what Habermas (1979) terms universal validity claims and which Simpson has adopted as a fundamental component of his model. According to Simpson, satirical uptake requires a special configuration of the three principal claims of sincerity, appropriateness, and truth. It is a kind of communication, between the writer and the reader, which depends on the ratification of the validity claims. Simpson adopts three of Habermas's four validity claims, neglecting the validity claim of comprehensibility.

The claim of comprehensibility indicates that the writer must write something comprehensible. If the satirical work is to be translated into another language, such as The Pessoptimist for example, the translator should take care of the cultural differences. This claim focuses on the question: "is this text comprehensible?" This claim is different from the other three in that it considers what is termed by Austin (1962) as the "perlocutionary" acts of readers who belong to different cultures and speak languages other than the writer's. According to Simpson's explanation of the validity claims, comprehensibility is the only claim that language itself raises, i.e., it is principally linguistic in character and takes no account of what Habermas terms "speech function". However, after applying Simpson's model and considering this validity claim, I conclude that the claim of comprehensibility may include both linguistic and cultural aspects rather than merely linguistic aspects. It is beyond argument that cultural differences can prevent the comprehensibility of a certain text even if the language used is very comprehensible. Consequently, if the claim of comprehensibility is not redeemed the satirical text will be confusing. This explains why some readers of Habiby's The Pessoptimist write in the following vein: "Maybe it's the cultural difference, but I just didn't understand this book at all," and "confusing satire reminiscent of Catch-22, though does have a grain of truth," ("Reviews of The Pessoptimist", 2013). Thus, even if there is a shared language, comprehensibility can be blocked as a result of cultural differences. That is why I suggest the inclusion of the fourth validity claim in the model.

\section{Conclusions}

Simpson's classification of satire as discourse permits satire to encompass a broad range of genres and take into consideration the reader's role. Although it is mainly formed as a result of analyzing satirical magazine articles, Simpson's model appears to be applicable to literary satirical works as well and novels in particular. Using science fiction as a vehicle for literary satire adds a new dimension to The Holy Land. Zubrin succeeds in making his readers see the familiar things through the eyes of strangers. In spite of its small size, The Pessoptimist is considered one of the masterpieces of Arabic literature. That it is translated into English widens the scope of its readers to include non-Arabs and helps to uncover new areas for the applicability of the model. As an engineer, Zubrin depends mainly on composing satirical structural images, and Habiby, as a politician, depends mainly on satirical talks and speeches. With the use of dots and diacritics, Arabic appears to be more able to provide various types of puns and wordplay techniques and, therefore, more effective satirical discourse.

Simpson's model is currently able to analyze literary satirical techniques used in novels with few exceptions. That is why this article suggests a couple of minor modifications. The first modification is related to the satirical method and the metonymic satirical method in particular. Placing the suggested technique of inversion under the metonymic satirical method besides saturation, attenuated focalization, and negation provides more clarification of the satirical method and more explanation why some literary pieces are satirical. In the same manner, the inclusion of Habermas's (1979) fourth validity claim, comprehensibility, besides sincerity, appropriateness, and truth helps readers to understand why satire sometimes misfires. No doubt, the suspension of the claim of comprehensibility because of cultural differences, in spite of having a shared language, will block the way for satirical effects.

\section{References}

Al-Hilai, M., \& Khan, M. (1983). Translation of the meanings of the Noble Qur'an in the English language. 
Madinah: King Fahd Complex for the printing of the Holy Qur'an.

"Aristophanes". (2013). In Encyclopcedia Britannica. Retrieved December 20, 2013, from http://www.britannica.com/EBchecked/ topic/34467/Aristophanes

Ashworth, P. (1967). Humor, irony and satire in the prose fiction of Ramón Pérez De Ayala (Doctoral dissertation). University of Oklahoma, Michigan.

Austin, J. (1962). How to do things with words. Oxford: Clarendon Press.

Ball, J. (1995). Satire and the post-colonial novel: V. S. Naipaul, Chinua Achebe, and Salman Rushdie (Doctoral dissertation). University of Toronto, Canada.

Beckson, K., \& Ganz, A. (1989). Literary terms: A dictionary. London: Andre Deutsch.

Berger, P. (1997). Redeeming laughter: The comic dimension of human experience. Berlin: Walter de Gruyter. http://dx.doi.org/10.1515/9783110810660

Bosworth, C. (1976). The mediaeval Islamic underworld: The Banu Sasan in Arabic society and literature. Leiden: Brill.

Broeder, L. (2007). Translating humour: The problems of translating Terry Pratchett (Master's thesis). University of Utrecht, Netherlands.

Cuddon. J. (1999). The Penguin dictionary of literary terms and literary theory (4th ed.). London: Penguin Books.

Fairclough, N. (1992). Discourse and social change. Cambridge: Polity Press. http://dx.doi.org/10.1177/0957926592003002008

Feinberg, L. (1972). Introduction to satire. Iowa: The Iowa State University Press.

Frye, N. (1957). Anatomy of criticism: Four Essays. Princeton: Princeton University Press.

Gill, J. (Ed.). (1995). Cutting edges: Postmodern critical essays on eighteenth century satire. Knoxville: University of Tennessee Press.

Gring-Pemble, L., \& Watson, M. (2003). The rhetorical limits of satire: An analysis of James Finn Garner's politically correct bedtime stories. Quarterly Journal of Speech, 89(2), 132-153. http://dx.doi.org/10.1080/00335630308175

Habermas, J. (1979). "What is universal pragmatics?" In T. McCarthy (Ed., \& Trans.), Communication and the evolution of society (pp. 1-68). London: Heinemann.

Habiby, E. (2003). The Secret Life of Saeed the Ill-fated Pessoptimist (S. K. Jayyusi, \& T. LeGassick, Trans.). Northampton: Interlink Books (Original work published 1974).

Harris, R. (2004). The purpose and method of satire. In Virtual Salt. Retrieved July 17, 2013, from http://www.virtualsalt.com/satire.htm

Hughes, A. (2009). The Holy Land by Robert Zubrin. In Fantastic Reviews. Retrieved July 10, 2013, from http://fantasticreviews.com/holy_land.htm

Jayyusi, S. K. (2003). Introduction. In E. Habiby, The secret life of Saeed the ill-fated pessoptimist (S. K. Jayyusi, \& T. LeGassick, Trans.). Northampton: Interlink Books.

Jianguo, W. (2011). Understanding interdiscursivity: A pragmatic model. Journal of Cambridge Studies, 6(2-3), 95-115.

Keppel, R., Weis, J., Brown, K., \& Welch, K. (2005). The Jack the Ripper murders: A modus operandi and signature analysis of the 1888-1891 Whitechapel murders. Journal of Investigative Psychology and Offender Profiling, 2(1), 1-21. http://dx.doi.org/10.1002/jip.22

Knight, C. (2004). The literature of satire. Cambridge: Cambridge University Press.

Kreuz, R., \& Glucksberg, S. (1989). How to be sarcastic: The echoic reminder theory of verbal irony. Journal of Experimental Psychology: General, 118(4), 374-386. http://dx.doi.org/10.1037/0096-3445.118.4.374

Kreuz, R., \& Roberts, R. (1993). On satire and parody: The importance of being ironic. Metaphor and Symbolic Activity, 8(2), 97-109. http://dx.doi.org/10.1207/s15327868ms0802_2

Lichtheim, M. (2006). Ancient Egyptian literature: Vol. 1. London: University of California Press.

Lutz, W. (2004). The Holy Land, by Robert Zubrin. In The Tocquevillian Magazine. Retrieved July 3, 2013, from http://www.tocquevillian.com/articles/0167.html 
Opitz, A. (2007). Impassioned sarcasm and militant irony: An investigation into the evolving politics of satire (Doctoral dissertation). The University of Minnesota, US.

Preminger, A., \& Brogan, T. (Eds.) (1993). The new Princeton encyclopaedia of poetry and poetics. Princeton: Princeton University Press.

Randall, C. (1974). Satire in the Bible (Doctoral dissertation). Hebrew Union College. Jewish Institute of Religion. Retrieved from Xerox University Microfilms, Ann Arbor, Michigan.

"Reviews of The Pessoptimist". (2013). In Goodreads. Retrieved July 1, 2013, from http://www.goodreads.com/ book/show/9412902-the-secret-life-of-saeed-the-pessoptimist

Rosenheim, E. (1971). Satiric spectrum. In R. Paulson (Ed.), Satire: Modern Essays in Criticism (pp. 305-329). New Jersey: Prentice-Hall.

Simpson, P. (2003). On the discourse of satire: Towards a stylistic model of satirical humour. Amsterdam: John Benjamin Publishing Company. http://dx.doi.org/10.1075/lal.2

Sperber, D., \& Wilson, D. (1981). Irony and the use-mention distinction. In P. Cole (Ed.), Radical Pragmatics (pp. 395-318). New York: Academic Press.

Sperber, D., \& Wilson, D. (1995). Relevance: Communication and Cognition (2nd ed.). Oxford: Blackwell.

Sperber, D., \& Wilson, D. (1998). Irony and relevance. In R. Carston, \& S. Uchida (Eds.), Relevance Theory: Applications and Implications (pp. 283-293). Amsterdam: John Benjamins.

Test, G. (1991). Satire: Spirit and art. Florida: University Press of Florida.

Weinbrot, H. (1988). Eighteenth-century satire. Cambridge: Cambridge University Press. http://dx.doi.org/10.1017/CBO9780511553561

Wilson, D., \& Sperber, D. (1992). “On verbal irony”. Lingua, 87, 53-76. http://dx.doi.org/10.1016/0024-3841(92)90025-E

Wilson, D., \& Sperber, D. (2012). Explaining irony. In D. Wilson, \& D. Sperber (Eds.), Meaning and Relevance (pp. 123-145). Cambridge: Cambridge University Press. http://dx.doi.org/10.1017/CBO9781139028370.008

Wilson, D. (2006). The pragmatics of verbal irony: Echo or pretence? Lingua, 116, 1722-1743. http://dx.doi.org/10.1016/j.lingua.2006.05.001

Wilson, D. (2012). Irony comprehension: A developmental perspective. Journal of Pragmatics. http://dx.doi.org/10.1016/j.pragma.2012.09.016

Zubrin, R. (2003). The Holy Land. Colorado: Polaris Books.

$$
\begin{aligned}
& \text { حبيبي، إميل. (1998). الوقائع الغريية في اختفاء سعبد أبي النحس الهتشائل . القاهرة: دار الهلال. }
\end{aligned}
$$

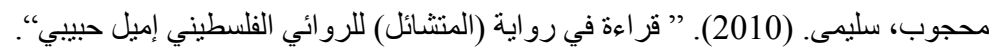

$$
\begin{aligned}
& \text { Retrieved from http://www.palmoon.net/5/topic-5936-163.html } \\
& \text { در اج، فيصل. (2004). ” رواية الكابوس الفلسطيني في بلاد الحواجز: عزمي بثارة في حب في منطقة الظل... الجهر بالحقيقة “. }
\end{aligned}
$$

\section{Notes}

Note 1. This type of satirical verse is called "هجاء" hijaa. It was used against the enemies of the poet's tribe to impugn their honour prior to battle or as "part of duels between poets of opposing tribes" (Test, 1991, p. 89).

Note 2. The translation of the excerpts of the novel is based on the translation by S. K. Jayyusi and T. LeGassick (2003).

Note 3. The translation of the verse is taken from Al-Hilai and Khan (1983, p. 39).

\section{Copyrights}

Copyright for this article is retained by the author(s), with first publication rights granted to the journal.

This is an open-access article distributed under the terms and conditions of the Creative Commons Attribution license (http://creativecommons.org/licenses/by/3.0/). 